\title{
Bullying behaviours and other conduct problems: longitudinal investigation of their independent associations with risk factors and later outcomes
}

\author{
Keertana Ganesan ${ }^{1} \cdot$ Sania Shakoor ${ }^{2}$. Jasmin Wertz ${ }^{3}$. Jessica Agnew-Blais ${ }^{4} \cdot$ Lucy Bowes $^{5} \cdot$ Sara R. Jaffee $^{6}$. \\ Timothy Matthews ${ }^{4} \cdot$ Louise Arseneault ${ }^{4}$ (i)
}

Received: 1 September 2020 / Accepted: 10 March 2021 / Published online: 15 April 2021

(c) The Author(s) 2021

\begin{abstract}
Purpose Bullying behaviours and other conduct problems often co-occur. However, we do not yet know whether bullying behaviours are associated with early factors and later poor outcomes independently of conduct problems. While there are differing, specific interventions for bullying behaviours and for conduct problems, it is unclear if such specificity is justified given parallels between both behaviours.

Methods We used prospective data from the Environmental Risk (E-Risk) Longitudinal Twin Study, a nationally representative sample of 2232 children. Mothers and teachers reported on children's bullying behaviours and conduct problems at ages 7 and 10. We collected measures of risk factors, including temperament and family factors, when children were age 5. We assessed behavioural, emotional, educational and social problems when participants reached the ages of 12 and 18.

Results Bullying behaviours and conduct problems co-occurred in childhood. Our findings indicated that bullying behaviours and other conduct problems were independently associated with the same risk factors. Furthermore, they were associated with the same poor outcomes at both ages 12 and 18. Despite this, bullying behaviours were uniquely associated with behavioural, emotional, educational and social problems at age 18.

Conclusions Our findings suggest that anti-bullying programmes and interventions aimed at reducing conduct problems could benefit from greater integration. Furthermore, our study highlights the mental health problems children who bully may face in later years and the need to consider those in intervention plans.
\end{abstract}

Keywords Bullying behaviours $\cdot$ Conduct problems $\cdot$ Longitudinal $\cdot$ Predictors $\cdot$ Outcomes

Louise Arseneault

louise.arseneault@kcl.ac.uk

1 Division of Psychology and Language Sciences, University College London, London, UK

2 Centre for Psychiatry, Wolfson Institute of Preventative Medicine, Queen Mary, University of London, London, UK

3 Department of Psychology and Neuroscience, Duke University, Durham, NC, USA

4 Social, Genetic, and Developmental Psychiatry Research Centre, Institute of Psychiatry, Psychology, and Neuroscience, King's College London, London, UK

5 Department of Experimental Psychology, University of Oxford, Oxford, UK

6 Department of Psychology, University of Pennsylvania, Philadelphia, PA, USA

\section{Introduction}

Bullying constitutes a form of repeated, intentional victimisation that commonly takes place between people of the same age group-including peers and siblings-where it is difficult for the victims to defend themselves [1]. Extensive evidence documents harmful outcomes associated with being bullied [2-5]. Findings also show that young people who bully others are at risk of engaging with criminal activities and antisocial behaviours [6]. However, it remains unclear the extent to which bullying behaviours are distinct from other conduct problems in childhood and adolescence and how best to intervene to reduce poor outcomes associated with these often co-occurring behaviours [7, 8].

Bullying behaviour is a criterion for a diagnosis of conduct disorder according to the American Psychiatric Association [9], and bullying could possibly be tackled similarly 
to other conduct problems. Programmes for reducing conduct problems are typically family-based and focus on parenting skills [10-12]. These programmes typically aim to enhance the knowledge, skills and confidence of parents to manage their children's behaviour [10]. However, the majority of interventions aimed at reducing bullying behaviours are school-based and focused on changing pupils' attitudes about bullying through discussions and role playing [6, 13]. There may be a case for augmenting these interventions with elements from interventions aimed at reducing conduct problems. In the present study, we explored the differences and similarities between bullying behaviours and other conduct problems to inform intervention and prevention strategies tackling these prevalent, harmful and costly behaviours [14-16].

Parallels between children who bully others and those with conduct problems can be drawn from epidemiological research. Studies have shown that bullying behaviours and conduct problems are associated with deficits in cognitive abilities such as IQ [17, 18], Theory of Mind [19, 20] and executive functioning [21,22]. Children who bully others and those with conduct problems are both more likely to have grown up in socioeconomically disadvantaged environments [23-25], and to have antisocial parents [17, 26]. The similarities between these two groups extend to later outcomes. Young people who bully others and those with conduct problems have elevated levels of behavioural and emotional problems [8, 27, 28], delinquency [29], substance use [30-32], difficulties at school [33,34], and they continue to show violent behaviours in adulthood [35]. Collectively, these findings indicate that bullying behaviours and other conduct problems overlap considerably and might not warrant different intervention approaches.

However, despite considerable similarities, bullying behaviours are arguably distinct from other conduct problems in that they target peers specifically and take place in the context of a power imbalance. The specificity of these behaviours could indicate that peer-related factors (i.e. peer group dynamics) may be particularly relevant for bullying in comparison to other conduct problems [36]; the dyadic relationship between children who bully and their victims could be key for bullying behaviours but not for other conduct problems [37]. Furthermore, bullying behaviours are uniquely associated with callous-unemotional traits, over and above other conduct problems [38]. This finding indicates that bullying behaviours may contribute unique variance to later poor outcomes, further reinforcing that they may be distinct from other conduct problems.

While studies have reported poor outcomes for young people who bully and those with other conduct problems, little research has directly compared to determine the extent to which they are unique. If findings indicate similar risk profiles across these behaviours, then the vast body of evidence that already exists on conduct problems could be used to inform our understanding of bullying behaviours and how to intervene to reduce their prevalence. Furthermore, examining bullying behaviours and other conduct problems in parallel could help ascertain their unique and cumulative contributions to later poor outcomes. Given the frequent cooccurrence of bullying behaviours and conduct problems, it is unclear if bullying behaviours independently predict adverse outcomes later in life, over and above conduct problems. It is possible that associations between bullying behaviours and later outcomes are accounted for by co-occurring conduct problems. Testing this will help address whether there is a need for specific interventions for bullying behaviours, or whether these behaviours could be tackled via existing interventions for conduct problems.

Using data from a UK nationally representative longitudinal cohort, the present study aimed to investigate (i) to what extent childhood bullying behaviours and conduct problems co-occur, (ii) whether established antecedents of conduct problems also predict bullying behaviours, (iii) whether childhood bullying behaviours independently predict behavioural/emotional problems and educational and social difficulties in early adolescence, over and above cooccurring conduct problems, and (iv) whether childhood bullying behaviours independently predict poor outcomes in young adulthood, after taking into account co-occurring conduct problems.

\section{Methods}

\section{Sample}

Participants were members of the Environmental Risk (E-Risk) Longitudinal Twin Study, which tracks the development of a birth cohort of 2232 British children. The sample was drawn from a larger birth register of twins born in England and Wales in 1994 and 1995 [39]. Full details about the sample are reported elsewhere [40]. Briefly, the E-Risk sample was constructed in 1999 and 2000, when 1,116 families (93\% of those eligible) with same-sex 5-year-old twins participated in home-visit assessments. This sample comprised 56\% monozygotic and 44\% dizygotic twin pairs; sex was evenly distributed within zygosity (49\% male).

Families were recruited to represent the UK population with newborns in the 1990s to ensure adequate numbers of children in disadvantaged homes and to avoid an excess of twins born to well-educated women using assisted reproduction. The study sample represents the full range of socioeconomic conditions in Great Britain, as reflected in the families' distribution on a neighbourhood-level socioeconomic index (A Classification of Residential Neighbourhoods, or ACORN, developed by CACI for commercial use) [41, 42]. 
Follow-up home visits were conducted when the children were 7 years of age (98\% participation), 10 years $(96 \%)$, 12 years (96\%), and 18 years (93\%). There were 2066 individuals who participated in the E-Risk assessments at age 18 . The average age of the participants at the time of the assessment was 18.4 years $(S D=0.36)$; all interviews were conducted after their 18th birthdays. There were no differences between participants who did and did not take part at age 18 in terms of socioeconomic status (SES) assessed when the cohort was initially defined, $\chi 2(2, N=2232)=0.86$, $p=0.65$; age-5 IQ scores, $t(2208)=0.98, p=0.33$; or age -5 emotional or behavioural problems, $t(2230)=0.40, p=0.69$, and $t(2230)=0.41, p=0.68$, respectively.

Home visits at ages 5, 7, 10, and 12 years included assessments with participants as well as their mother (or primary caretaker). Teachers' reports were collected via postal questionnaires (posted to the children's teachers, with parents' permission). The home visit at age 18 included interviews only with the participants. The joint South London and Maudsley-Institute of Psychiatry, Psychology \& Neuroscience Ethics Committee approved each phase of the study. Parents gave informed consent and twins gave assent between 5 and 12 years and then informed consent at age 18 years.

\section{Measures}

\section{Bullying behaviours and other conduct problems}

We assessed bullying behaviours using mothers' and teachers' reports when participants were ages 7 and 10 with items from the Children's Behavior Checklist [43] and Teacher's Report Form [44] ('bullying or threatening people', 'cruel or nasty to other people', and 'teases a lot' and teachers' report for the items 'cruelty, bullying, or meanness to others', 'teases a lot', and 'threatens people'). Mothers and teachers were asked to rate each item as being 'not true' (0), 'somewhat or sometimes true' (1), or 'very or often true' (2). The internal consistency for the combined mother and teacher ratings was 0.66 at age 7 and 0.69 at 10 .

We assessed conduct problems-other than bullying behaviours-at ages 7 and 10 using items from the Delinquent Behavior (e.g., 'lying or cheating') and Aggressive Behavior scales (e.g., 'temper tantrums or hot temper') of the Child Behavior Checklist [43] and Teacher's Report Form [44], supplemented with DSM-IV items assessing conduct disorder (e.g., 'stays out at night past the time he/ she should be home'). The internal consistency reliabilities for combined ratings from mothers and teachers were 0.93 at age 7 and 0.94 at age 10 .

Scores were averaged across informant and time to create a summary measure capturing pervasive and persistent bullying behaviours and other conduct problems. Combining mother and teacher ratings allowed us to capture behaviours in different settings (i.e. school and home environments). Inter-rater reliability estimates were comparable between the bullying behaviour scales (age-7 mothers-teachers $r=0.23$; age-10 mothers-teachers $r=0.25$ ) and the conduct problem scales (age-7 mothers-teachers $r=0.30$; age-10 mothers-teachers $r=0.30$ ).

\section{Risk factors and outcomes of bullying and other conduct problems}

We selected possible predictors and outcomes of bullying behaviours and other conduct problems based on previous research. Details are reported in Table 1.

\section{Statistical analyses}

First, we calculated correlations to examine the extent to which bullying behaviours and conduct problems co-occurred at ages 7 and 10. Second, we used linear regression models to test whether childhood risk factors were associated with bullying behaviours and conduct problems. More specifically, we examined whether risk factors predicted bullying behaviours and conduct problems individually in bivariate models. Furthermore, we examined whether these risk factors predicted bullying behaviours and other conduct problems after controlling for each other. Third, using linear and logistic regression models, we tested whether bullying behaviours and conduct problems at ages 7 and 10 were similarly associated with later difficulties at ages 12 and 18. Initially, we tested whether each outcome was associated with bullying behaviours and conduct problems separately in bivariate models. To test the unique contributions of childhood bullying behaviours, we tested whether each outcome was associated with bullying in multivariate models controlling for concurrent childhood conduct problems. The same strategy was employed to examine the unique contribution of childhood conduct problems where concurrent childhood bullying behaviours were controlled for.

We used moderation analyses to check whether the associations differed by sex. Regression analyses with sex-interaction terms did not yield significant improvements in the fit of models above and beyond models with main effects only. Thus, analyses conducted for the whole sample were collapsed across sex. We used the Huber-White or Sandwich estimator [45] to obtain robust standard errors, to account for the nonindependence of twin data. All analyses were conducted using Stata 12.0 [46]. 
Table 1 Measures of bullying behaviours, conduct problems, antecedents and outcomes

$\begin{array}{llll}\text { Measure } \quad \text { Informant } \quad \text { Mean (SD) or \% Observed range } & \begin{array}{l}\text { Inter-rater } \\ \text { reliability } \\ (r)\end{array} & \text { Reference citations } \\ & & \end{array}$

\begin{tabular}{|c|c|c|c|c|c|c|}
\hline $\begin{array}{l}\text { Bullying and other conduct } \\
\text { problems }\end{array}$ & & & & & & \\
\hline Bullying behaviours & $\begin{array}{l}\text { Child Behavior Checklist } \\
\text { (CBCL), Teacher Report } \\
\text { Form (TRF) }\end{array}$ & Mother, Teacher & $0.61(0.74)$ & $0-5$ & $0.66-0.69$ & [69] \\
\hline Other conduct problems & $\begin{array}{l}\text { Child Behavior Checklist } \\
\text { (CBCL), Teacher Report } \\
\text { Form (TRF), DSM-IV } \\
\text { Items }\end{array}$ & Mother, Teacher & $0.86(1.21)$ & $0-8.5$ & $0.93-0.94$ & [43] \\
\hline Age-5 predictors & & & & & & \\
\hline $\begin{array}{l}\text { Undercontrolled tempera- } \\
\text { ment }\end{array}$ & $\begin{array}{l}\text { Children's approach and } \\
\text { response to interview }\end{array}$ & Interviewer & $2.41(3.63)$ & $0-18$ & - & {$[70]$} \\
\hline Child maltreatment & $\begin{array}{l}\text { Adapted parenting inter- } \\
\text { view schedule }\end{array}$ & Mother & 14 & $0-1$ & 0.9 & {$[71,72]$} \\
\hline Low maternal warmth & $\begin{array}{l}\text { Maternal expressed emo- } \\
\text { tion scale based on the } \\
\text { 5-min speech sample } \\
\text { method }\end{array}$ & Rater coded & $3.30(1.00)$ & $0-5$ & 0.9 & [73] \\
\hline Domestic violence & $\begin{array}{l}\text { Conflicts Tactics Scale and } \\
3 \text { items assessing other } \\
\text { abusive behaviours }\end{array}$ & Mother & 42 & $0-1$ & - & {$[74]$} \\
\hline $\begin{array}{l}\text { Parents' antisocial } \\
\text { behaviour }\end{array}$ & $\begin{array}{l}\text { Young adult behaviour } \\
\text { checklist supplemented } \\
\text { with questions from } \\
\text { Diagnostic Interview } \\
\text { Schedule (DIS) for } \\
\text { DSM-IV }\end{array}$ & Mother & 27.58 & $0-1$ & - & {$[75,76]$} \\
\hline $\begin{array}{l}\text { Low socio-economic } \\
\text { status }\end{array}$ & $\begin{array}{l}\text { Standardized composite of } \\
\text { income, education and } \\
\text { social class modelled } \\
\text { on the British Social } \\
\text { Attitudes survey }\end{array}$ & Mother & 33.24 & $0-1$ & - & {$[77]$} \\
\hline Age-12 outcomes & & & & & & \\
\hline Antisocial behaviour & $\begin{array}{l}\text { Computer task based on } \\
\text { DSM }\end{array}$ & Self-report & $2.46(2.94)$ & $0-24$ & - & {$[78]$} \\
\hline Substance use & $\begin{array}{l}\text { Computer based question- } \\
\text { naire }\end{array}$ & Self-report & $0.21(0.53)$ & $0-5$ & - & - \\
\hline Depression symptoms & $\begin{array}{l}\text { Children's Depression } \\
\text { Inventory (CDI) }\end{array}$ & Self-report & $3.11(5.32)$ & $0-42$ & - & [79] \\
\hline Anxiety symptoms & $\begin{array}{l}\text { Multidimensional Anxi- } \\
\text { ety Scale for Children } \\
\text { (MASC) with interview }\end{array}$ & Self-report & $7.62(3.04)$ & $0-18$ & - & {$[80]$} \\
\hline Academic difficulties & $\begin{array}{l}\text { Computer based question- } \\
\text { naire }\end{array}$ & Self-report & $0.34(0.60)$ & $0-2$ & - & - \\
\hline Low popularity & $\begin{array}{l}\text { Computer based question- } \\
\text { naire }\end{array}$ & Self-report & 26.57 & $0-1$ & - & - \\
\hline Age-18 outcomes & & & & & & \\
\hline Antisocial behaviour & $\begin{array}{l}\text { Interview based on Diag- } \\
\text { nostic and Statistical } \\
\text { Manual of Mental Disor- } \\
\text { ders (DSM-IV) criteria }\end{array}$ & Self-report & $2.12(2.28)$ & $0-11$ & - & {$[76]$} \\
\hline Criminal behaviour & $\begin{array}{l}\text { UK Police National } \\
\text { Computer (PNC) record } \\
\text { searches }\end{array}$ & Official record & 10.78 & $0-1$ & - & - \\
\hline
\end{tabular}


Table 1 (continued)

\begin{tabular}{|c|c|c|c|c|c|c|}
\hline & Measure & Informant & Mean (SD) or $\%$ & Observed range & $\begin{array}{l}\text { Inter-rater } \\
\text { reliability } \\
(r)\end{array}$ & Reference citations \\
\hline $\begin{array}{l}\text { Alcohol dependence } \\
\text { symptoms }\end{array}$ & $\begin{array}{l}\text { Interview based on Diag- } \\
\text { nostic and Statistical } \\
\text { Manual of Mental Disor- } \\
\text { ders (DSM-IV) criteria }\end{array}$ & Self-report & $1.13(1.67)$ & $0-11$ & - & [76] \\
\hline $\begin{array}{l}\text { Cannabis dependence } \\
\text { symptoms }\end{array}$ & $\begin{array}{l}\text { Interview based on Diag- } \\
\text { nostic and Statistical } \\
\text { Manual of Mental Disor- } \\
\text { ders (DSM-IV) criteria }\end{array}$ & Self-report & $0.24(0.98)$ & $0-7$ & - & [76] \\
\hline Depression symptoms & $\begin{array}{l}\text { Interview based on Diag- } \\
\text { nostic and Statistical } \\
\text { Manual of Mental Disor- } \\
\text { ders (DSM-IV) criteria }\end{array}$ & Self-report & $1.81(2.97)$ & $0-9$ & - & [76] \\
\hline Anxiety symptoms & $\begin{array}{l}\text { Interview based on Diag- } \\
\text { nostic and Statistical } \\
\text { Manual of Mental Disor- } \\
\text { ders (DSM-IV) criteria }\end{array}$ & Self-report & $0.95(1.82)$ & $0-6$ & - & [76] \\
\hline Academic difficulties & $\begin{array}{l}\text { Not in Education, Employ- } \\
\text { ment, or Training } \\
\text { (NEET) interview }\end{array}$ & Self-report & 11.57 & $0-1$ & - & [81] \\
\hline Social isolation & $\begin{array}{l}\text { Scale of Perceived Social } \\
\text { Support (MSPSS) }\end{array}$ & Self-report & $3.29(4.34)$ & $0-24$ & 0.88 & {$[82]$} \\
\hline
\end{tabular}

\section{Results}

\section{To what extent do bullying behaviours and other conduct problems co-occur in childhood?}

Children's bullying behaviours at ages 7 and 10 went handin-hand with other conduct problems. Bullying behaviours and conduct problems were significantly correlated at age $7(r=0.62, p<0.001)$ and age $10(r=0.66, p<0.001)$. In addition to this, bullying behaviours and conduct problems were significantly correlated across time points $(r>0.4$, $p<0.001)$. Figure 1 illustrates that very few participants showed frequent bullying behaviours in the absence of other conduct problems, and vice versa.

\section{Are age-5 risk factors associated with childhood bullying behaviours and other conduct problems?}

Children who at age 5 had an undercontrolled temperament, had been exposed to low maternal warmth, maltreatment or domestic violence, had parents with antisocial behaviour, or who had experienced socioeconomic disadvantage showed more frequent bullying behaviours and conduct problems compared to children who were not exposed to these risk factors (Table 2). Associations with these risk factors and bullying behaviours reduced after accounting for concurrent conduct problems; only low maternal warmth remained independently associated with bullying behaviours, indicating that this risk factor is specifically associated with children's bullying behaviours, independent of other conduct
Fig. 1 Overlap between bullying behaviours and other conduct problems

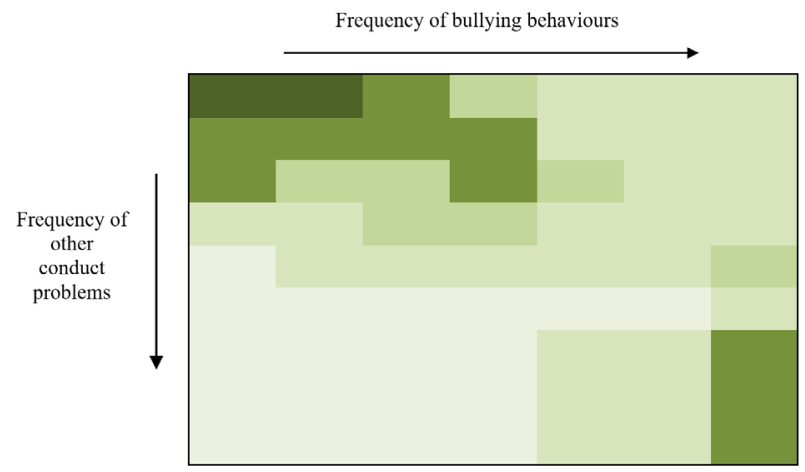


Table 2 Models predicting bullying behaviours from children's early adversity and co-occurring conduct problems from bivariate and multivariate analysis

\begin{tabular}{|c|c|c|c|c|}
\hline & \multicolumn{3}{|c|}{ Age- 7 and 10 bullying behaviours and conduct problems } & \multirow[b]{2}{*}{$\begin{array}{l}\text { Conduct problems control- } \\
\text { ling for bullying behav- } \\
\text { iours }\end{array}$} \\
\hline & Bullying behaviours & Conduct problems & $\begin{array}{l}\text { Bullying behaviours controlling } \\
\text { for other conduct problems }\end{array}$ & \\
\hline Age-5 predictors & $\beta(95 \% \mathrm{CI})$ & $\beta(95 \% \mathrm{CI})$ & $\beta(95 \% \mathrm{CI})$ & $\beta(95 \% \mathrm{CI})$ \\
\hline Undercontrolled temperament & $0.15(0.09,0.21)$ & $0.16(0.10,0.23)$ & $0.04(0.00,0.07)$ & $0.06(0.02,0.10)$ \\
\hline Child maltreatment & $0.16(0.10,0.21)$ & $0.13(0.07,0.19)$ & $0.07(0.03,0.10)$ & $0.02(-0.02,0.06)$ \\
\hline Low warmth & $0.09(0.02,0.16)$ & $0.13(0.05,0.20)$ & $0.00(-0.04,0.04)$ & $0.06(0.02,0.11)$ \\
\hline Domestic violence & $0.20(0.15,0.26)$ & $0.16(0.11,0.22)$ & $0.09(0.05,0.12)$ & $0.02(-0.02,0.06)$ \\
\hline Parents' antisocial behaviour & $0.23(0.17,0.29)$ & $0.22(0.15,0.28)$ & $0.08(0.05,0.12)$ & $0.06(0.02,0.09)$ \\
\hline Low socioeconomic status & $0.20(0.15,0.26)$ & $0.17(0.11,0.23)$ & $0.09(0.05,0.12)$ & $0.03(-0.01,0.07)$ \\
\hline
\end{tabular}

Significant associations have been shown in bold

Associations are expressed as standardised regression coefficients $(\beta)$ with 95\% Confidence Interval (CI). Residuals of regression analysis with bullying behaviours and conduct problem were normally distributed. Log-transformation of variables did not affect the observed associations

problems. Undercontrolled temperament, low maternal warmth and parents' antisocial behaviour also predicted conduct problems after adjustment for co-occurring bullying behaviours.

\section{Are bullying behaviours and other conduct problems in childhood independently associated with poor outcomes at age 12 ?}

Frequent bullying behaviours and other conduct problems predicted worse outcomes at age 12. Bullying behaviours and conduct problems were both associated with higher levels of behavioural problems later on and increased symptoms of depression (Table 3 ). Associations with anxiety did not reach statistical significance. Only conduct problems were associated with more educational and social problems. After adjusting for conduct problems, bullying behaviours were no longer significantly associated with later depression. Additionally, effect sizes for antisocial behaviour and substance use were attenuated by between 37 and 39\%, but remained statistically significant. In contrast, after adjusting for bullying behaviours,

Table 3 Models predicting age-12 outcomes with childhood bullying behaviours and conduct problems

\begin{tabular}{|c|c|c|c|c|c|c|}
\hline \multirow[b]{3}{*}{ Age $7 / 10$} & \multicolumn{6}{|l|}{ Age-12 outcomes } \\
\hline & \multicolumn{2}{|c|}{ Behavioural problems } & \multicolumn{2}{|l|}{ Emotional problems } & \multicolumn{2}{|c|}{ Educational and social difficulties } \\
\hline & $\begin{array}{l}\text { Antisocial behav- } \\
\text { iour }\end{array}$ & Substance use & $\begin{array}{l}\text { Depression symp- } \\
\text { toms }\end{array}$ & Anxiety symptoms & $\begin{array}{l}\text { Academic difficul- } \\
\text { ties }\end{array}$ & Low popularity \\
\hline & $\beta(95 \% \mathrm{CI})$ & $\beta(95 \% \mathrm{CI})$ & $\beta(95 \% \mathrm{CI})$ & $\beta(95 \% \mathrm{CI})$ & $\beta(95 \% \mathrm{CI})$ & OR $(95 \% \mathrm{CI})$ \\
\hline \multicolumn{7}{|l|}{$\begin{array}{l}\text { Unadjusted for co- } \\
\text { occurrence }\end{array}$} \\
\hline $\begin{array}{l}\text { Bullying behav- } \\
\text { iours }\end{array}$ & $0.30(0.24,0.36)$ & $0.18(0.12,0.24)$ & $0.14(0.07,0.20)$ & $0.01(-0.04,0.06)$ & $0.13(0.07,0.20)$ & $1.10(0.99,1.23)$ \\
\hline Conduct problems & $0.29(0.23,0.36)$ & $0.18(0.12,0.24)$ & $0.21(0.13,0.28)$ & $0.04(-0.02,0.10)$ & $0.17(0.10,0.25)$ & $1.22(1.10,1.35)$ \\
\hline \multicolumn{7}{|l|}{$\begin{array}{l}\text { Adjusted for } \\
\text { co-occurring } \\
\text { problems at ages } 7 \\
\text { and } 10\end{array}$} \\
\hline $\begin{array}{l}\text { Bullying behav- } \\
\text { iours }\end{array}$ & $0.19(0.11,0.26)$ & $0.11(0.04,0.19)$ & $\begin{array}{l}-0.02(-0.08, \\
0.05)\end{array}$ & $\begin{array}{c}-0.03(-0.10, \\
0.03)\end{array}$ & $0.02(-0.05,0.08)$ & $0.90(0.78,1.07)$ \\
\hline Conduct problems & $0.16(0.09,0.23)$ & $0.10(0.02,0.18)$ & $0.22(0.13,0.31)$ & $0.06(-0.01,0.13)$ & $0.16(0.08,0.25)$ & $1.30(1.12,1.51)$ \\
\hline
\end{tabular}

OR $(95 \% \mathrm{CI}$ - —odds ratio with $95 \%$ confidence interval. $\beta(95 \% \mathrm{CI})$-beta coefficient value with $95 \%$ confidence interval

Significant associations have been shown in bold 


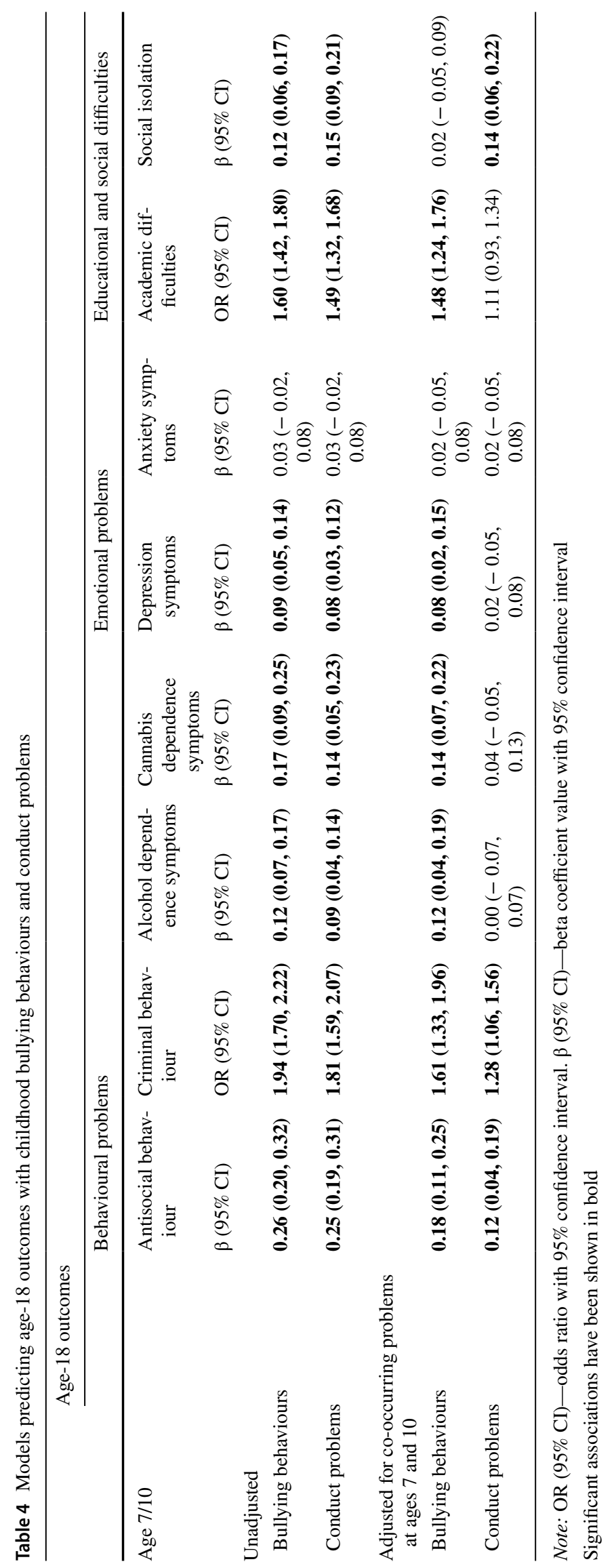


conduct problems remained significantly associated with all outcomes, with associations attenuated by between 5 and $45 \%$.

\section{Are bullying behaviours and other conduct problems in childhood independently associated with poor outcomes at age 18 ?}

Similar to age-12 outcomes, we observed that frequent bullying behaviours and other conduct problems were associated with poor outcomes at age 18. Bullying behaviours and conduct problems were associated with antisocial and criminal behaviours, symptoms of alcohol and cannabis dependence, symptoms of depression, and educational and social difficulties (Table 4). Once more, we did not find statistically significant associations with symptoms of anxiety. After adjusting for conduct problems at age 12, associations with bullying behaviours and age- 18 outcomes remained moderate and statistically significant (though attenuated up to $31 \%$ ). After adjusting for bullying behaviours, associations between other conduct problems and symptoms of alcohol and cannabis dependence, depression and academic difficulties became non-significant. Associations between conduct problems with antisocial behaviour, criminal behaviour and social isolation remained significant (though reduced by between 7 and 52\%).

\section{Discussion}

Who are those children who bully others and what can we do to tackle these behaviours? Findings from our nationally representative longitudinal cohort of British children shed light on these questions and provide new insight uncovering whether children who bully others and those with conduct problems are distinct from one another. First, we showed that bullying behaviours do not occur in isolation and are most often accompanied by other conduct problems. Second, well-established risk factors for childhood conduct problems are also associated with bullying behaviours, independently of other conduct problems. Third, despite the overlap between both types of behaviours and their shared predictors, they independently predict poor outcomes in later life. This suggests that bullying behaviours and other conduct problems may be better addressed by multi-level interventions that include parents, teachers, and peers.

Simultaneously examining bullying behaviours and other conduct problems allowed us to compare and contrast the profiles of both behaviours and examine their specificity. Our study provides evidence that children who bully others and those with conduct problems share many characteristics. This builds on prior research that looked at these groups separately [1, 23-26, 47]. Children who bully and those with other conduct problems were both at increased risk of developing poor outcomes in early adolescence and young adulthood, independently of each other. Our findings highlight that bullying behaviours may foreshadow antisocial and criminal behaviours in later life, in a similar manner to other conduct problems [48]. In addition to showing continuity over time, both types of behaviours were also associated with later depression, as well as educational and social problems, but not with anxiety. These findings highlight that children who bully develop behavioural, emotional, educational and social problems, similar to children with other conduct problems [33, 49].

Despite showing similarities between the two types of behaviours, our findings indicate that bullying behaviours uniquely contributed to later poor outcomes. In early adolescence, bullying behaviours were independently associated with antisocial behaviour, substance use and low popularity. In young adulthood, they were independently associated with all types of behavioural problems, and also depression and academic difficulties. The association with depression may potentially be explained by the social nature of bullying behaviours. Because bullying takes place between peers, it may impinge on the likelihood of establishing positive peer relationships which are important sources of support for young people [50, 51]. Social support has been found to buffer against mental health problems in times of stress [52]. Indeed, studies have found that those who have a stronger social support network and high-quality friendships have lower emotional and behavioural problems than children without [53,54]. While some studies reported that young people who bully were considered popular by their peers [55-57], this may not reflect positive and supportive relationships that are needed to reduce the risk of mental health problems. The longitudinal association with depression expands upon previous literature showing that behavioural problems in early childhood predict emotional problems in mid-childhood [8, 23, 49, 58], with one meta-analysis showing that childhood bullying specifically contributes to later depression [59]. Our findings are consistent with a 'failure' model [60], which proposes that youth with behavioural problems develop emotional problems as they grow older because of the negative experiences they have encountered as they grow up including academic failures and poor family and peer relationships. These findings highlight the detrimental nature of childhood bullying and its unique contribution to later poor outcomes extending into young adulthood.

This brings us to discuss the limits of our study. First, we did not have any measures that would have allowed us to examine peer factors that may be centric to the uniqueness of bullying behaviours. Examining peer dynamics and interpersonal functioning with peers could further clarify why bullying behaviours uniquely contribute to later problems. Second, we did not use a standardised instrument specific 
to assessing bullying behaviours. Rather we extracted items relevant to bullying behaviours from an instrument used to assess a variety of problem behaviours more broadly. Nevertheless, we identified antecedents and later outcomes amongst children who bully similar to those shown in previous studies that used standardized bullying measures [8, $29,35,61]$, suggesting construct validity. Furthermore, we used both mothers' and teachers' reports to measure bullying and conduct problems, which may capture behaviours observed in different settings [62] and reduce concerns related to shared method variance. Second, when investigating the similarities between children who bully and children with other conduct problems, we did not distinguish between the types of bullying and conduct problems. This would have allowed us to further investigate the underlying mechanisms that contribute towards the similarities and differences between children who bully and children with other conduct behaviours. Third, young adult outcomes were restricted to age 18, and therefore long-term outcomes were not captured with these data. However, age 18 is a critical period for the developmental trajectory of antisocial behaviours [63-66], and thus behaviours measured at this time point may be key to capture salient poor outcomes. Fourth, we restricted the analyses to examining bullying behaviours and conduct problems in childhood only. We did not examine how later bullying and conduct problems in mid-childhood may uniquely contribute to problems in later years. Therefore, our findings are specific to outcomes of earlier bullying and conduct problems. The onset of bullying behaviours in adolescence may potentially have a varied unique contribution to later problems which future research is required to examine. Fifth, as our study includes twin pairs, it is unclear if results are generalisable to the population. However, previous studies have found the rates of psychopathology in singletons and twins are comparable [67]. Sixth, we did not test if controlling for earlier risk factors mitigates the associations observed between bullying behaviours and later poor outcomes. It is possible that these risk factors account for any observed associations between bullying behaviours and poor outcomes. However, this does not take away from the take home message that bullying behaviours independently increase the risk for emotional and behavioural problems later on.

Our findings have implications for future research and interventions. Despite the overlap between bullying behaviours and conduct problems, our findings suggest there is value in examining bullying behaviours specifically as they are associated with worse outcomes later on. In addition, our findings demonstrate the importance of controlling for conduct problems when investigating the outcomes associated with bullying behaviours. Some associations between bullying behaviours and poor outcomes became non-significant after adjusting for co-occurring conduct problems. This highlights the risk of spurious correlations when conduct problems are not accounted for. Finally, our findings may help inform interventions targeting bullying behaviours. Our study suggests that interventions aimed at preventing bullying behaviours could be combined with those tackling conduct problems, given similar sets of risks factors for both types of behaviours. Specifically, like conduct problems, bullying behaviours were associated with risk factors within the family environment. This suggests that although bullying is often regarded as schools' responsibility to tackle, our findings suggest that it is necessary for interventions targeting bullying behaviours to include a family component, rather than being exclusively school-based. In particular, Fast Track targeting conduct problems is multisite, targeting behaviours both at home and at school [68]. Bullying behaviours may benefit from such multisite interventions, addressing familial factors that may contribute to bullying behaviours alongside targeting bullying behaviours at school. Moreover, our findings emphasise that we need to acknowledge children who bully others may also experience emotional problems. Interventions should not only focus on curbing their antisocial behaviours but should also consider their risk of facing later depression and other educational and social problems.

In conclusion, the present study showed that bullying behaviours frequently co-occur and share risk factors with other conduct problems, suggesting that interventions aiming to prevent these behaviours could be combined. However, our findings also showed that these behaviours uniquely contribute to poor outcomes both in mid-childhood and adulthood. Thus, programmes aiming to reduce poor outcomes among children showing these types of behaviours should regard bullying behaviours distinctly and consider mental health needs for children who bully others.

Acknowledgements The E-Risk Study is funded by the Medical Research Council (UKMRC grant G1002190). Additional support was provided by National Institute of Child Health and Human Development (grant HD077482) and by the Jacobs Foundation. Jasmin Wertz is supported by a postdoctoral fellowship by the AXA Research Fund. Jessica Agnew-Blais is an MRC Skills Development Fellow. Lucy Bowes is supported by a Springboard Award from the Academy of Medical Sciences. Timothy Matthews is a British Academy Postdoctoral Fellow. Louise Arseneault is the Mental Health Leadership Fellow for the UK Economic and Social Research Council. The authors are grateful to the study members and their families for their participation. Our thanks to Terrie E Moffitt and Avshalom Caspi, the founders of the E-Risk Study, CACI, Inc., and to members of the E-Risk team for their dedication, hard work, and insights.

\section{Declarations}

Conflict of interest The authors declares that they have no conflict of interest. 
Ethical approval The joint South London and Maudsley-Institute of Psychiatry, Psychology \& Neuroscience Ethics Committee approved each phase of the study.

Open Access This article is licensed under a Creative Commons Attribution 4.0 International License, which permits use, sharing, adaptation, distribution and reproduction in any medium or format, as long as you give appropriate credit to the original author(s) and the source, provide a link to the Creative Commons licence, and indicate if changes were made. The images or other third party material in this article are included in the article's Creative Commons licence, unless indicated otherwise in a credit line to the material. If material is not included in the article's Creative Commons licence and your intended use is not permitted by statutory regulation or exceeds the permitted use, you will need to obtain permission directly from the copyright holder. To view a copy of this licence, visit http://creativecommons.org/licenses/by/4.0/.

\section{References}

1. Olweus D (1993) Bullying at school: what we know and what we can do. Bullying at school: what we know and what we can do. Blackwell Publishing, Malden

2. Klomek AB, Sourander A, Elonheimo H (2015) Bullying by peers in childhood and effects on psychopathology, suicidality, and criminality in adulthood. Lancet Psychiatry 2(10):930-941. https://doi.org/10.1016/S2215-0366(15)00223-0

3. McDougall P, Vaillancourt T (2015) Long-term adult outcomes of peer victimization in childhood and adolescence: pathways to adjustment and maladjustment. Am Psychol 70(4):300-310. https://doi.org/10.1037/a0039174

4. Wolke D, Lereya ST (2015) Long-term effects of bullying. Arch Dis Child 100(9):879-885. https://doi.org/10.1136/archdischi ld-2014-306667

5. Arseneault L (2018) Annual research review: the persistent and pervasive impact of being bullied in childhood and adolescence: implications for policy and practice. J Child Psychol Psychiatry 59(4):405-421. https://doi.org/10.1111/jcpp.12841

6. Ttofi MM, Farrington DP (2011) Effectiveness of school-based programs to reduce bullying: a systematic and meta-analytic review. J Exp Criminol 7(1):27-56. https://doi.org/10.1007/ s11292-010-9109-1

7. Copeland WE, Wolke D, Angold A, Costello EJ (2013) Adult psychiatric outcomes of bullying and being bullied by peers in childhood and adolescence. JAMA Psychiatry 70(4):419-426. https://doi.org/10.1001/jamapsychiatry.2013.504

8. Nansel TR, Overpeck M, Pilla RS, Ruan WJ, Simons-Morton B, Scheidt P (2001) Bullying behaviors among US youth: prevalence and association with psychosocial adjustment. JAMA 285(16):2094-2100. https://doi.org/10.1001/jama.285.16.2094

9. American Psychiatric Association (2013) Diagnostic and statistical manual of mental disorders, 5th edn. Author, Arlington, VA

10. de Graaf I, Speetjens P, Smit F, de Wolff M, Tavecchio L (2008) Effectiveness of the Triple P Positive Parenting Program on behavioral problems in children: a meta-analysis. Behav Modif 32(5):714-735. https://doi.org/10.1177/0145445508317134

11. Scott S, Briskman J, O'Connor TG (2014) Early prevention of antisocial personality: long-term follow-up of two randomized controlled trials comparing indicated and selective approaches. Am J Psychiatry 171(6):649-657. https://doi.org/10.1176/appi. ajp.2014.13050697

12. Fonagy P, Butler S, Cottrell D, Scott S, Pilling S, Eisler I, Fuggle P, Kraam A, Byford S, Wason J, Ellison R, Simes E, Ganguli P, Allison E, Goodyer IM (2018) Multisystemic therapy versus management as usual in the treatment of adolescent antisocial behaviour (START): a pragmatic, randomised controlled, superiority trial. Lancet Psychiatry 5(2):119-133. https://doi.org/10. 1016/S2215-0366(18)30001-4

13. Farrington DP, Ttofi MM (2009) School-based programs to reduce bullying and victimization. Campbell Syst Rev 5(1):i-148. https:// doi.org/10.4073/csr.2009.6

14. Scott E, Dale J, Russell R, Wolke D (2016) Young people who are being bullied — do they want general practice support? BMC Fam Pract 17(1):116. https://doi.org/10.1186/s12875-016-0517-9

15. Brimblecombe N, Evans-Lacko S, Knapp M, King D, Takizawa R, Maughan B, Arseneault L (2018) Long term economic impact associated with childhood bullying victimisation. Soc Sci Med 208:134-141. https://doi.org/10.1016/j.socscimed.2018.05.014

16. Rivenbark JG, Odgers CL, Caspi A, Harrington H, Hogan S, Houts RM, Poulton R, Moffitt TE (2018) The high societal costs of childhood conduct problems: evidence from administrative records up to age 38 in a longitudinal birth cohort. J Child Psychol Psychiatry 59(6):703-710. https://doi.org/10.1111/jcpp.12850

17. Farrington D, Baldry A (2010) Individual risk factors for school bullying. J Aggress Confl Peace Res 2(1):4-16. https://doi.org/ 10.5042/jacpr.2010.0001

18. Goodman R, Simonoff E, Stevenson J (1995) The impact of child IQ, parent IQ and sibling IQ on child behavioural deviance scores. J Child Psychol Psychiatry 36(3):409-425. https://doi. org/10.1111/j.1469-7610.1995.tb01299.x

19. Shakoor S, Jaffee SR, Bowes L, Ouellet-Morin I, Andreou P, Happe F, Moffitt TE, Arseneault L (2012) A prospective longitudinal study of children's theory of mind and adolescent involvement in bullying. J Child Psychol Psychiatry 53(3):254261. https://doi.org/10.1111/j.1469-7610.2011.02488.x

20. Sharp C (2008) Theory of mind and conduct problems in children: deficits in reading the "emotions of the eyes." Cogn Emot 22(6):1149-1158. https://doi.org/10.1080/02699930701667586

21. Coolidge FL, DenBoer JW, Segal DL (2004) Personality and neuropsychological correlates of bullying behavior. Pers Individ Dif 36(7):1559-1569. https://doi.org/10.1016/j.paid.2003.06. 005

22. Morgan AB, Lilienfeld SO (2000) A meta-analytic review of the relation between antisocial behavior and neuropsychological measures of executive function. Clin Psychol Rev 20(1):113-136. https://doi.org/10.1016/S0272-7358(98)00096-8

23. Moffitt TE (2007) A review of research on the taxonomy of lifecourse persistent versus adolescence-limited antisocial behavior. In: The Cambridge handbook of violent behavior and aggression. Cambridge University Press, New York, NY, US, pp 49-74. https://doi.org/https://doi.org/10.1017/CBO9780511816840.004

24. Bowes L, Arseneault L, Maughan B, Taylor A, Caspi A, Moffitt TE (2009) School, neighborhood, and family factors are associated with children's bullying involvement: a nationally representative longitudinal study. J Am Acad Child Adolesc Psychiatry 48(5):545-553. https://doi.org/10.1097/CHI.0b013e31819cb017

25. Jansen DEMC, Veenstra R, Ormel J, Verhulst FC, Reijneveld SA (2011) Early risk factors for being a bully, victim, or bully/victim in late elementary and early secondary education. The longitudinal TRAILS study. BMC Public Health 11(1):440. https://doi.org/ 10.1186/1471-2458-11-440

26. Smith CA, Farrington DP (2004) Continuities in antisocial behavior and parenting across three generations. J Child Psychol Psychiatry 45(2):230-247. https://doi.org/10.1111/j.1469-7610.2004. 00216.x

27. Sentse M, Kretschmer T, de Haan A, Prinzie P (2017) Conduct Problem trajectories between age 4 and 17 and their association with behavioral adjustment in emerging adulthood. J Youth Adolesc 46(8):1633-1642. https://doi.org/10.1007/s10964-016-0476-4 
28. Lichtenstein P, Cederlöf M, Lundström S, D’Onofrio BM, Anckarsäter H, Larsson H, Pettersson E (2019) Associations between conduct problems in childhood and adverse outcomes in emerging adulthood: a longitudinal Swedish nationwide twin cohort. J Child Psychol Psychiatry. https://doi.org/10.1111/jcpp.13169

29. Barker ED, Arseneault L, Brendgen M, Fontaine N, Maughan B (2008) Joint development of bullying and victimization in adolescence: relations to delinquency and self-harm. J Am Acad Child Adolesc Psychiatry 47(9):1030-1038. https://doi.org/10.1097/ CHI.ObO13e31817eec98

30. Fergusson DM, Horwood LJ, Ridder EM (2007) Conduct and attentional problems in childhood and adolescence and later substance use, abuse and dependence: results of a 25-year longitudinal study. Drug Alcohol Depend 88(Suppl 1):S14-26. https://doi. org/10.1016/j.drugalcdep.2006.12.011

31. Niemela S, Brunstein-Klomek A, Sillanmaki L, Helenius H, Piha J, Kumpulainen K, Moilanen I, Tamminen T, Almqvist F, Sourander A (2011) Childhood bullying behaviors at age eight and substance use at age 18 among males. A nationwide prospective study. Addict Behav 36(3):256-260. https://doi.org/10.1016/j. addbeh.2010.10.012

32. Kretschmer T, Hickman M, Doerner R, Emond A, Lewis G, Macleod J, Maughan B, Munafò MR, Heron J (2014) Outcomes of childhood conduct problem trajectories in early adulthood: findings from the ALSPAC study. Eur Child Adolesc Psychiatry 23(7):539-549. https://doi.org/10.1007/s00787-013-0488-5

33. Murray-Harvey R, Slee PT (2010) School and home relationships and their impact on school bullying. Sch Psychol Int 31(3):271295. https://doi.org/10.1177/0143034310366206

34. Erskine HE, Norman RE, Ferrari AJ, Chan GC, Copeland WE, Whiteford HA, Scott JG (2016) Long-term outcomes of attentiondeficit/hyperactivity disorder and conduct disorder: a systematic review and meta-analysis. J Am Acad Child Adolesc Psychiatry 55(10):841-850. https://doi.org/10.1016/j.jaac.2016.06.016

35. Farrington DP, Ttofi MM (2011) Bullying as a predictor of offending, violence and later life outcomes. Crim Behav Ment Health 21(2):90-98. https://doi.org/10.1002/cbm.801

36. Salmivalli $\mathrm{C}$ (2010) Bullying and the peer group: a review. Aggress Violent Behav 15(2):112-120. https://doi.org/10.1016/j. avb.2009.08.007

37. Rodkin PC, Hanish LD, Wang S, Logis HA (2014) Why the bully/ victim relationship is so pernicious: a gendered perspective on power and animosity among bullies and their victims. Dev Psychopathol 26(3):689-704. https://doi.org/10.1017/S095457941 4000327

38. Viding E, Simmonds E, Petrides KV, Frederickson N (2009) The contribution of callous-unemotional traits and conduct problems to bullying in early adolescence. J Child Psychol Psychiatry 50(4):471-481. https://doi.org/10.1111/j.1469-7610.2008.02012.x

39. Trouton A, Spinath FM, Plomin R (2002) Twins early development study (TEDS): a multivariate, longitudinal genetic investigation of language, cognition and behavior problems in childhood. Twin Res 5(5):444-448. https://doi.org/10.1375/1369052023 20906255

40. Moffitt TE, E-Risk Study Team (2002) Teen-aged mothers in contemporary Britain. J Child Psychol Psychiatry 43(6):727-742. https://doi.org/10.1111/1469-7610.00082

41. Odgers CL, Caspi A, Bates CJ, Sampson RJ, Moffitt TE (2012) Systematic social observation of children's neighborhoods using Google Street View: a reliable and cost-effective method. J Child Psychol Psychiatry 53(10):1009-1017. https://doi.org/10.1111/j. 1469-7610.2012.02565.x

42. Odgers CL, Caspi A, Russell MA, Sampson RJ, Arseneault L, Moffitt TE (2012) Supportive parenting mediates neighborhood socioeconomic disparities in children's antisocial behavior from ages 5 to 12. Dev Psychopathol 24(3):705-721. https://doi.org/10. 1017/S0954579412000326

43. Achenbach TM (1991) Manual for the Child Behavior Checklist/4-18 and 1991 Profiles. Department of Psychiatry, University of Vermont, Burlington, VT

44. Achenbach TM (1991) Manual for the Youth Self-Report and 1991 Profiles. University of Vermont Department of Psychiatry, Burlington, VT

45. Williams RL (2000) A note on robust variance estimation for cluster-correlated data. Biometrics 56(2):645-646. https://doi. org/10.1111/j.0006-341x.2000.00645.x

46. StataCorp (2011) Stata statistical software: release 12. StataCorp LP, College Station, TX

47. Bowers L, Smith PK, Binney V (1994) Perceived family relationships of bullies, victims and bully/victims in middle childhood. J Soc Pers Relat 11(2):215-232. https://doi.org/10.1177/02654 07594112004

48. McGee TR, Hayatbakhsh MR, Bor W, Cerruto M, Dean A, Alati R, Mills R, Williams GM, O'Callaghan M, Najman JM (2011) Antisocial behaviour across the life course: an examination of the effects of early onset desistence and early onset persistent antisocial behaviour in adulthood. Aust J Psychol 63(1):44-55. https:// doi.org/10.1111/j.1742-9536.2011.00006.x

49. Wertz J, Zavos H, Matthews T, Harvey K, Hunt A, Pariante CM, Arseneault L (2015) Why some children with externalising problems develop internalising symptoms: testing two pathways in a genetically sensitive cohort study. J Child Psychol Psychiatry 56(7):738-746. https://doi.org/10.1111/jcpp.12333

50. Schmidt A, Dirk J, Schmiedek F (2019) The importance of peer relatedness at school for affective well-being in children: betweenand within-person associations. Soc Dev 28(4):873-892. https:// doi.org/10.1111/sode.12379

51. Goodboy AK, Martin MM, Rittenour CE (2016) Bullying as a display of social dominance orientation. Commun Res Rep 33(2):159-165. https://doi.org/10.1080/08824096.2016.1154838

52. Lee J-S, Koeske GF, Sales E (2004) Social support buffering of acculturative stress: a study of mental health symptoms among Korean international students. Int J Intercult Relat 28(5):399-414. https://doi.org/10.1016/j.ijintrel.2004.08.005

53. Holt MK, Espelage DL (2007) Perceived social support among bullies, victims, and bully-victims. J Youth Adolesc 36(8):984994. https://doi.org/10.1007/s10964-006-9153-3

54. Bollmer JM, Milich R, Harris MJ, Maras MA (2005) A friend in need: the role of friendship quality as a protective factor in peer victimization and bullying. J Interpers Violence 20(6):701-712. https://doi.org/10.1177/0886260504272897

55. Guy A, Lee K, Wolke D (2019) Comparisons between adolescent bullies, victims, and bully-victims on perceived popularity, social impact, and social preference. Front Psychiatry 10:868. https://doi. org/10.3389/fpsyt.2019.00868

56. Romera EM, Bravo A, Ortega-Ruiz R, Veenstra R (2019) Differences in perceived popularity and social preference between bullying roles and class norms. PLoS ONE 14(10):e0223499. https:// doi.org/10.1371/journal.pone.0223499

57. van der Ploeg R, Steglich C, Veenstra R (2020) The way bullying works: How new ties facilitate the mutual reinforcement of status and bullying in elementary schools. Soc Netw 60:71-82. https:// doi.org/10.1016/j.socnet.2018.12.006

58. Reef J, Diamantopoulou S, van Meurs I, Verhulst F, van der Ende J (2010) Predicting adult emotional and behavioral problems from externalizing problem trajectories in a 24-year longitudinal study. Eur Child Adolesc Psychiatry 19(7):577-585. https://doi.org/10. 1007/s00787-010-0088-6

59. Ttofi MM, Farrington DP, Losel F, Loeber R (2011) The predictive efficiency of school bullying versus later offending: a 
systematic/meta-analytic review of longitudinal studies. Crim Behav Ment Health 21(2):80-89. https://doi.org/10.1002/cbm.808

60. Patterson GR, Stoolmiller M (1991) Replications of a dual failure model for boys' depressed mood. J Consult Clin Psychol 59(4):491-498. https://doi.org/10.1037//0022-006x.59.4.491

61. Wolke D, Copeland WE, Angold A, Costello EJ (2013) Impact of bullying in childhood on adult health, wealth, crime, and social outcomes. Psychol Sci 24(10):1958-1970. https://doi.org/10. 1177/0956797613481608

62. Achenbach TM, McConaughy SH, Howell CT (1987) Child/ adolescent behavioral and emotional problems: implications of cross-informant correlations for situational specificity. Psychol Bull 101(2):213-232

63. Moffitt TE (1997) Adolescence-limited and life-course-persistent offending: a complementary pair of developmental theories. Developmental theories of crime and delinquency. Advances in criminological theory. Transaction Publishers, Piscataway, NJ, US, pp 11-54

64. Sawyer MG, Arney FM, Baghurst PA, Clark JJ, Graetz BW, Kosky RJ, Nurcombe B, Patton GC, Prior MR, Raphael B, Rey JM, Whaites LC, Zubrick SR (2001) The mental health of young people in Australia: key findings from the child and adolescent component of the national survey of mental health and wellbeing. Aust N Z J Psychiatry 35(6):806-814. https://doi.org/ 10.1046/j.1440-1614.2001.00964.x

65. Hemphill SA, Toumbourou JW, Herrenkohl TI, McMorris BJ, Catalano RF (2006) The effect of school suspensions and arrests on subsequent adolescent antisocial behavior in Australia and the United States. J Adolesc Health 39(5):736-744. https://doi. org/10.1016/j.jadohealth.2006.05.010

66. Moffitt TE (2018) Male antisocial behaviour in adolescence and beyond. Nat Hum Behav 2:177-186. https://doi.org/10.1038/ s41562-018-0309-4

67. Gjone H, Nøvik TS (1995) Parental ratings of behaviour problems: a twin and general population comparison. J Child Psychol Psychiatry 36(7):1213-1224. https://doi.org/10.1111/j. 1469-7610.1995.tb01366

68. Conduct Problems Prevention Research Group (1992) A developmental and clinical model for the prevention of conduct disorders: the FAST Track Program. Dev Psychopathol 4(4):509-527

69. Achenbach TM (1991) Integrative guide for the 1991 CBCL/418 , YRS and TRF profiles. University of Vermont Department of Psychiatry, Burlington, VT

70. Caspi A, Henry B, McGee R, Moffitt TE, Silva PA (1995) Temperamental origins of child and adolescent behavior problems: from 3 to age 15. Child Dev 66:55-68. https://doi.org/10.1111/j. 1467-8624.1995.tb00855.x
71. Dodge KA, Bates JE, Pettit GS (1990) Mechanisms in the cycle of violence. Science 250(4988):1678-1683. https://doi.org/10. $1126 /$ science. 2270481

72. Jaffee SR, Caspi A, Moffitt TE, Taylor A (2004) Physical maltreatment victim to antisocial child: evidence of an environmentally mediated process. J Abnorm Psychol 113(1):44-55. https:// doi.org/10.1037/0021-843X.113.1.44

73. Caspi A, Moffitt TE, Morgan J, Rutter M, Taylor A, Arseneault L, Tully L, Jacobs C, Kim-Cohen J, Polo-Tomas M (2004) Maternal expressed emotion predicts children's antisocial behavior problems: using monozygotic-twin differences to identify environmental effects on behavioral development. Dev Psychol 40(2):149-161. https://doi.org/10.1037/0012-1649. 40.2.149

74. Straus MA (1990) Measuring intrafamily conflict and violence: the Conflict Tactics (CT) Scales. Transaction, New Brunswick, NJ

75. Achenbach TM (1997) Manual for Young Adult Self-Report and Young Adult Behavior Checklist. University of Vermont, Department of Psychiatry, Burlington

76. Robins L, Cottler L, Bucholz K, Compton W (1995) Diagnostic Interview Schedule for DSM-IV. Washington University School of Medicine, St. Louis

77. Jowell R, Cutice J, Park A, Brook L, Thomson K, Bryson C (1997) British social attitudes: the 14th report. Ashgate, Aldershot, England

78. American Psychiatric Association (2000) Diagnostic and statistical manual of mental disorders, 4th edn. Author, Washington, DC

79. Kovacs M, Goldston D, Obrosky DS, Iyengar S (1992) Prevalence and predictors of pervasive noncompliance with medical treatment among youths with insulin-dependent diabetes mellitus. J Am Acad Child Adolesc Psychiatry 31(6):1112-1119. https://doi. org/10.1097/00004583-199211000-00020

80. March JS, Parker JD, Sullivan K, Stallings P, Conners CK (1997) The Multidimensional Anxiety Scale for Children (MASC): factor structure, reliability, and validity. J Am Acad Child Adolesc Psychiatry 36(4):554-565. https://doi.org/10.1097/00004583-19970 4000-00019

81. Goldman-Mellor S, Caspi A, Arseneault L, Ajala N, Ambler A, Danese A, Fisher H, Hucker A, Odgers C, Williams T, Wong C, Moffitt TE (2016) Committed to work but vulnerable: self-perceptions and mental health in NEET 18-year olds from a contemporary British cohort. J Child Psychol Psychiatry 57(2):196-203. https://doi.org/10.1111/jcpp.12459

82. Zimet GD, Dahlem NW, Zimet SG, Farley GK (1988) The Multidimensional scale of perceived social support. J Pers Assess 52(1):30-41. https://doi.org/10.1207/s15327752jpa5201_2 